\title{
Tax Management Analysis of Coal Companies Post Amendment to Work Agreement for Coal Mining Enterprises 3rd Generation: A Case Study
}

\author{
Tetta Aurora \\ Accounting Department, Economics and Business Faculty \\ Universitas Indonesia \\ Jakarta, Indonesia \\ Magister of Accounting
}

\author{
Christine \\ Accounting Department, Economics and Business Faculty \\ Universitas Indonesia \\ Jakarta, Indonesia \\ indivara_devi@yahoo.com
}

\begin{abstract}
This research analyzed implications of the Indonesian government's 3rd Generation CCoW Amendment to the Company's Effective Tax Rate and Tax Management, which was a mandate of Law No. 4, 2009, on Mineral and Coal Mining (the Minerba Law), which stipulated that the provisions in $\mathrm{CCOW}$ mining concessions must be amended accordingly. One main change was increased state revenues in that taxation provisions changed from the 1994 law to the prevailing law. This research discusses tax management applied by a company after the tax regime change that covers tax administration, planning, and strategy if there is a tax audit. The research used a case study approach with a qualitative method. The unit of analysis was a CCoW Generation 3 coal company located in East and Central Kalimantan. Results revealed that the $\mathrm{CCOW}$ amendment increased the effective tax rate tax management; therefore, efficiency is needed for tax planning of corporate income tax, for instance, in submission of Specific Areas, supervision of Debt to Equity Ratio (DER), and so on. In addition to tax planning, companies should also apply administrative compliance according to prevailing provisions to avoid any interest or penalties. This research can also serve as an evaluation of the CCoW amendment policy undertaken by the Indonesian central government.
\end{abstract}

Keywords-tax management, tax planning, effective tax rate, coal, ccow generation 3, amendment

\section{INTRODUCTION}

In Indonesia, coal is an important energy commodity. According to the Global Energy Statistical Yearbook, 2017, Indonesia was the fifth largest coal producer, with total production of 456 million tons in 2016. Coal exploitation in Indonesia began with issuance of Law No. 1, 1967, concerning foreign investment. Since 1967, coal in Indonesia has been exploited by companies with the Work Agreement for Coal Mining Enterprises (CCoW), with the first generation from 1981 to 1993 , the second from 1993 to 1996, and the third from 1996 to 2000.

In 2009, the Indonesian government issued Law No. 4, 2009, on Mineral and Coal Mining (the Minerba Law), which stipulates that mining business can be conducted only by holders of a Mining Business License (IUP). The law states that provisions for mining concessions listed in the CCoW must accord with the Minerba Act no later than 1 year after January 12, 2009, except for state revenues. This triggered renegotiation for the CCoW amendment, in which previous taxation provisions in compliance with the original
CCoW changed into prevailing laws and regulations, its amendments, additions, and/or substitutes (prevailing law).

The CCoW amendment increased state revenues. On the other hand, companies' tax burden also increased, so coal companies carefully considered agreement on tax provision change when renegotiating the amendment, which contains many provisions differing from previous prevailing provisions, for instance, revocation of certain formerly deductible expenses. Another was a value added tax (VAT) provision that coal was a taxable good, so all tax input could be credited; however, prevailing provisions stipulate that coal no longer a taxable good, so all input tax cannot be credited. Changes in taxation provisions were disadvantageous to $\mathrm{CCoW}$ entrepreneurs, who must manage their taxes to make the tax burden more efficient.

This research aimed to discover the tax burden on PT X through Effective Tax Rate (ETR; before and after the CCoW amendment) and what tax management PT X should conduct post CCoW amendment.

Previous research is the thesis Tax Treatment of 1st Generation Coal Mining Company (Case Study of PT. X) by Ariya Somanatta [1] from Magister of Accounting University Indonesia in 2003. The research gap stretches from that research into first generation $\mathrm{CCoW}$ tax treatment and auditing to this research's examination of third generation tax provisions. This research can benefit decision makers who are selecting tax management to minimize the tax burden and make it efficient.

\section{THEORIES AND LITERATURE REVIEW}

\section{A. Tax Management}

Tax management is a comprehensive effort undertaken by individual taxpayers and agencies in a process of planning, implementation, and controlling obligations and tax rights so that matters relating to taxation of individuals, companies, or organizations can be managed well, efficiently, and effectively, thereby contributing the maximum to the individual or the company [2].

According to Lumbantoruan, cited in Suandy [3], tax management is a means of meeting tax obligations correctly while keeping the amount of tax paid as low as possible, in order to obtain expected profit and liquidity. Suandy further stated that tax management's purpose can be divided into 
applying proper taxation rules and efficiency efforts to achieve intended profit [3]

\section{1) Tax Planning}

Tax planning means ensuring that a company's tax is paid truly efficiently. Its main purpose is discovering various loopholes in tax regulations so that companies can pay the minimum amount.

\section{2) Tax Compliance}

Tax compliance involves efforts to meet tax administration obligations by properly calculating taxes according to taxation provisions and paying and reporting taxes within established time limits. Compliance further includes withholding tax correctly with respect to engineering, management, construction, and professional services, along with other kinds of withholding tax, and creation of correct tax invoices and VAT collection, among others.

\section{3) Tax Audit}

In this research, tax audit includes strategies in handling tax audits and responding to their results and strategies in submitting objection letters or appeals.

\section{4) Other Tax Related Matters}

Other functions related to taxation include, for instance, communicating provisions of tax systems and procedures to interested parties or company departments and training for staff in taxation matters [2].

\section{B. Effective Tax Rate}

The ETR describes both the cumulative effect of analysis of various tax incentives and changes in corporate tax rates. The type of ETR depends on the type of research conducted [4]. This study used average ETR, that is, tax ratio paid to net income (tax paid to income).

$$
\text { Average ETR }=\frac{\text { Tax Paid }}{\text { Income }}
$$

In "Which Effective Tax Rate?" Fullerto (1984) defines average ETR as "observed corporate tax divided by secured corporate income," meaning that average ETR is taxes compared/divided by income. In Statement of Financial Accounting Standards (PSAK), revision 46, 2017, section 86 also states that ETR represents tax expense (income) divided by accounting income.

\section{Taxation for Company of 3rd Generation of CCoW}

The provision act applicable at the time the contract is signed is those provisions in force in 1994 (CCoW PTX, 1998), among which are:

1. Law No. 10, 1994, regarding corporate income tax.

2. Law No. 11, 1994, regarding VAT on goods and services and sales tax on luxury goods.

3. Law No. 9, 1994, concerning general taxation provisions.

4. Other provisions set forth in the CCoW.

\section{Prevailing Tax Laws}

The CCoW amendment stipulates that taxation provisions shall refer to applicable laws and regulations, applicable supplements and/or substitutes. The principle of prevailing provision is that contracts are guided by occasional changes to laws and regulations. Current prevailing, applicable laws include:

1. Law No. 36, 2008, regarding income tax law [5].

2. Law No. 42, 2009, regarding VAT on goods and services and sales tax on luxury goods [6].

3. Law No. 28, 2007, regarding general taxation provisions [7].

\section{1) Other provisions in the CCoW amendment}

Table 1 shows a summary comparison of changes to taxation provisions on the original $\mathrm{CCoW}$ and the $3 \mathrm{rd}$ Generation CCoW. However, some provisions and the amount of royalties did not change.

\section{RESEARCH METHOD}

This research used a qualitative method and a case study approach with single unit analysis. The data source was primary data and research instruments such as interviews Ministry of Energy and Mineral Resources (ESDM) also Directorate General Tax (DGT) and content analysis.

TABLE I. COMPARISON OF CHANGES $3^{\text {RD }}$ GENERATION CCOW AMENDMENTS

\begin{tabular}{|l|l|l|}
\hline \multicolumn{1}{|c|}{ Description } & \multicolumn{1}{c|}{ Original CCoW } & CCoW Amendment \\
\hline CIT tax rate & Progressive: $10 \%, 20 \%, 30 \%$ & $25 \%$ \\
\hline Benefit in Kind (BIK) & Deductible & Nondeductible \\
\hline Loss carried forward & 8 years & 5 years \\
\hline VAT & Coal is a taxable goods and PT X as VAT Collector & Coal is a taxable goods and PT X is non VAT Collector \\
\hline Royalty & $13.5 \%$ & $13.5 \%$ \\
\hline Dead rent & USD 3/Ha/year (Annex D) & USD 4/Ha/year \\
\hline Import duty and import tax & Free & Free providing that Masterlist is available \\
\hline Land and building tax & Dead rent $+(0.5 \% \mathrm{x} 30 \% \times$ Gross Profit) & $0.5 \% \mathrm{x} 40 \% \mathrm{x} 10.25 \times$ Net Profit \\
\hline
\end{tabular}




\section{A. Research Methods}

Creswell (2014) [8] states that qualitative research is an approach to explore and understand the meaning of individuals or groups considered a social or humanitarian problem. Qualitative research involves questions and procedures, data gathering, data analysis built inductively, and then interpretation of meaning.

A qualitative approach is useful for generating in-depth descriptions of speech, writing, and observable behavior of an individual, community, group, or organization in a tentative context studied from a comprehensive and holistic perspective. Qualitative methods ensure that obtained data will be relatively more complete, in-depth, credible, and meaningful so that research objectives can be achieved (Sugiyono, 2008).

This research qualitatively analyzed the implications of the 3rd Generation CCoW, the amendment of which changed taxation provisions for coal companies. This study describes changes in the terms and the tax burden borne by PT X, the case study company. Then, after analysis of taxation changes, the researcher formulated efficient tax management for the company. As part of tax management, the researcher also discussed tax planning, which can be formulated from provisions set forth in the amendment.

Because case studies are used to explore a phenomenon in detail, in this case, changes in tax provisions, the research process included the following stages: obtaining data from the unit of analysis; conducting interviews with practitioners, academics, and the government; and processing data as a basis for analysis and interpretation. In this study, data were extracted from the Audit Report of the State Audit Board of the Republic of Indonesia, Years 2010, 2011, 2012, and 2013, for all Indonesian provinces. Data on public complaints about corruption were gathered from Indonesia's Central Bureau of Statistics.

\section{B. Data Collection}

In this study, data were collected as follows:

\section{1) Primary data}

Primary data, including financial statements, company conditions, and opinion sources, were obtained via interviews from company PT X, the unit of analysis.

\section{2) Secondary Data}

To support the argument, researchers also used secondary data, including, for instance, coal production reports, tax regulations, and so on, accessed through public domains such as websites or via socialization on the Internet.

\section{Technique Analysis (Research Instrument)}

Qualitative research methods in this study consisted of, among others, two main types:

\section{1) Interviews}

Interviews with resource persons are social interactions undertaken to collect valid data and information [9]. In this study, interviews were conducted with practitioners and academics, using open-ended questions to gather information and opinions on the $\mathrm{CCoW}$ amendment's tax implications and potential tax management. In terms of policy makers, researchers also conducted interviews with ESDM, DGT, and the Fiscal Policy Board (BKF).

\section{2) Content Analysis}

Researchers analyzed content by critically examining various documents related to the research, checking and analyzing financial statement documents, contract agreements, and interview results from resource persons.

Analytical steps were:

a. Looking for tax regulatory information for the mining industry.

b. Seeking tax incentives from applicable tax laws so that tax planning could be conducted.

c. Collecting financial data from the research object.

d. Conducting interviews with resource persons.

e. Establishing a tax planning and tax administration plan.

After calculating the tax burden (ETR), the researcher could see differences in the company's tax burden before and after the CCoW amendment. Tax planning analysis was used with descriptive qualitative analysis techniques, via prevailing tax regulations, to determine administrative and incentive provisions that could be utilized. In addition, the researcher used interview data as the basis of taxation management policy that needed review and implementation after the CCoW amendment.

\section{Research Object}

The unit of analysis was a CCoW 3rd Generation coal company in Murung Raya and Barito Utara District, Central Kalimantan Province and a small part of Mahakam Ulu Regency, East Kalimantan Province. The original CCoW was signed on September 6, 2000, and Amended on November 14, 2017. Production is \pm 1.000 .000 Mton and is overburden 7.034.500 $\mathrm{Bcm}$. The type of coal is semi cooking.

Activities undertaken by PTX in the operational period included land clearing, excavation of topsoil, overburden stripping, coal mining, coal hauling to ports, barging, and marketing. During 2017, coal mining realized 933,979 tons from the initial plan of $1,016,775$ tons. Sales during 2017 were 877,210 tons consisting of 845.248 tons of export and 31,962 tons for domestic sales. Table II displays net profit for PT X:

TABLE II. NeT PRofit PT X

\begin{tabular}{|l|l|}
\hline \multicolumn{1}{|c|}{ Description } & \multicolumn{1}{c|}{ Amount (USD) } \\
\hline Net Profit percommercial & 4.618 .932 \\
\hline Revenue on final tax & 25.653 \\
\hline Positive Fiscal Correction & 7.382 .515 \\
\hline Negative Fiscal Correction & $(4.744 .920)$ \\
\hline Net Praofit perfiscal & $\mathbf{7 . 2 3 0 . 8 7 4}$ \\
\hline
\end{tabular}

\section{ANALYSIS}

\section{A. Calculation of Tax Expense (ETR) on PTX}

Components of tax calculation at PT X with 2017 data, as follows: 


\section{1) Value Added Tax (VAT)}

\section{a) VAT before the CCoW amendment}

Prior to the CCoW amendment, coal was a taxable good so that the input tax obtained for coal production could be credited with the output tax. Input tax excess could be refunded.

\section{b) VAT after the CCoW amendment}

Since the coal amendment, CCoW is no longer a VATable good, so input tax on the acquisition of BKP/JKP to produce coal cannot be credited. This created an additional burden of input tax that could not be credited to PT X, amounting to 73.009.522.232. However, input tax that could not be credited can be charged as corporate income expense so that PT X obtains tax savings on corporate income tax of $25 \% \mathrm{x}$ input tax. So, effectively, the additional input tax burden equaled $75 \% \quad$ x $\operatorname{Rp} 73,009,522,232=\mathrm{Rp}$. $54,757,141,674$.

\section{2) Land and Building Tax}

Pre-amendment land and building tax based on SPPT 2017 was Rp. 2,921,845,028; afterward, it was USD $13,867,632,915$. In other words, prevailing tariffs raised land and building tax by $475 \%$.

\section{3) Royalties}

In accordance with the $\mathrm{CCoW}$ amendment, the amount of royalties did not change, i.e., $13.5 \%$ of the production of USD $10,981,712$.

\section{4) Fixed Contributions and Other Non-tax Revenues}

Post-amendment, the amount of fixed contribution rate changed from USD $3 /$ ha to USD $4 /$ ha. However, other nontax revenues did not change. The amount of total tax expense pre-amendment was USD 338,990 and post-amendment, it was USD 345,121.

\section{5) Corporate Income Tax}

\section{a) Before the CCoW Amendment}

The amount of corporate income tax from taxable income of $\mathrm{Rp}$. $7,230,874$ with a progressive rate of $0 \%$ to $30 \%$ was USD $2,167,512$.

\section{b) After the CCoW Amendment}

Post-amendment, the CCoW calculation uses a $25 \%$ tariff. The prevailing provision contains additional fiscal correction for the natura fee of USD 3,708.18 to obtain the company's income tax expense of USD 2,734,763.

\section{B. Effective Tax Rate Calculation}

ETR was calculated by eliminating the tax ratio paid to the net income (tax paid to income).

$$
\text { Average ETR }=\frac{\text { Tax } \text { Paid }}{\text { Income }}
$$

Table III shows calculation of income (profit before tax) in USD.

From the calculation shows that with the amendment of $\mathrm{CCoW}$ there is an ETR increase of $6 \%$. Government policy to increase state revenues in this case to PT $\mathrm{X}$ has been achieved, but the burden of taxes borne by PT X is higher.

TABLE III. COMPARISON OF EFFECTIVE TAX RATE

\begin{tabular}{|l|l|r|r|}
\hline \multirow{2}{*}{ No } & \multirow{2}{*}{ Description } & \multicolumn{2}{|c|}{ Amount (USD) } \\
\cline { 3 - 4 } & & $\begin{array}{c}\text { Original } \\
\text { CCOW }\end{array}$ & \multicolumn{1}{c|}{$\begin{array}{c}\text { Amendment } \\
\text { CCOW }\end{array}$} \\
\hline 1 & VAT & - & $4,035,459$ \\
\hline 2 & Land and Building Tax & 215,332 & $1,002,008$ \\
\hline 3 & Royalty & $10,981,716$ & $10,981,716$ \\
\hline 4 & Dearent & 338,990 & 345,121 \\
\hline 5 & CIT & $13,703,550$ & $19,119,068$ \\
\hline & Total & $18,322,482$ & $23,738,000$ \\
\hline 6 & Net Profit Before Tax & $75 \%$ & $81 \%$ \\
\hline 7 & Effective Tax Rate (ETR) & & $2,734,764$ \\
\hline
\end{tabular}

\section{Calculation of Tax Expense (ETR) on PT X}

1) Income Tax

Previous to fiscal year 2018, the Income Tax Act 1994 and Appendix F of CCoW remained in effect. Beginning in fiscal year 2018, however, prevailing provisions changed, specifically Income Tax Law No. 36, 2008, (UU-36/2008) along with its implementing regulations.

\section{a) Paying Attention to Debt to Equity Ratio (DER) Calculation}

DER calculation shall apply provisions of Regulation of the Minister of Finance No. 169/PMK.010/2015 regarding Determination of the Amount of Between Debt and Company's Capital for the Calculation of Income Tax, which stipulates that the ratio of debt and capital is set at a maximum of 4:1. Article 2, Paragraph (1) of PMK169/2015 states, "The amount of comparison between debt and capital as referred to in Article 1 paragraph (1) shall be set at the maximum ratio four to one (4:1)".

If the DER exceeds 4: 1 , then the overpaid interest becomes a nondeductible expense. Notably, the DER ratio is 4: 1 so that all interest costs associated with a loan can be deductible expense in accordance with applicable regulations.

DER PT X was calculated in USD, as in Table VI.

1). PT X Debt in 2017

2). Equity PT $X 2017$

3). Interest Expense in 2017 was USD 2,066,622.

4). Table VI displays calculation of DER before and after the CCoW Amendment

TABLE IV. DEBT OF PT X

\begin{tabular}{|l|r|}
\hline Liabilities & \multicolumn{1}{|c|}{ Amount } \\
\hline Current liabilities & 469,757 \\
\hline Trade payables & $8,180,897$ \\
\hline Accrued expenses & $1,106,757$ \\
\hline Taxes payable & 969,250 \\
\hline Short-term employee benefit liabilities & $\mathbf{1 0 , 7 2 6 , 6 6 1}$ \\
\hline Subtotal Current liabilities & $6,574,365$ \\
\hline Non-current liabilities & 407,696 \\
\hline Provision for decommissioning and mine closure & $61,389,510$ \\
\hline Post employee benefit liabilities & $\mathbf{6 8 , 3 7 1 , 5 7 1}$ \\
\hline Loans from related parties - non-current portion & $\mathbf{7 9 , 0 9 8 , 2 3 2}$ \\
\hline \multicolumn{2}{|c|}{ Subtotal non-current liabilities } \\
\hline Total Liabilities &
\end{tabular}


TABLE VII.

TABLE V. EQUITY OF PT X

\begin{tabular}{|l|l|}
\hline Equity & Amount \\
\hline Share capital & $316,977,156$ \\
\hline Accumulated losses & $(210,459,336)$ \\
\hline Total Equity & $\mathbf{1 0 6 , 5 1 7 , 8 2 0}$ \\
\hline
\end{tabular}

Based on the data in Table IV and $\mathrm{V}$, below is the DER calculation of PT X:

TABLE VI. COMParison Der Calculation of PT X

\begin{tabular}{|l|l|l|}
\hline Description & Before CCoW Amendment & After CCoW Amendment \\
\hline DER Ratio & $8: 1=$ debt to paid up capital & $4: 1=$ debt to equity \\
\hline Calculation & 61 mio US\$:316 mio US\$ & 61 mio US\$:106 mio US\$ \\
\hline Ratio & $0,19 \mathrm{x}$ & $0,57 \mathrm{x}$ \\
\hline
\end{tabular}

DER ratio has not been exceeded, so all interest cost is deductible expense. However, if compared with DER before the CCoW amendment, the DER ratio has increased, and PT $\mathrm{X}$ needs to pay attention because in 2018, prevailing rules increased the DER ratio. Furthermore, 2018 should also be considered; if debt is conducted by a related party, the company must referred to the Arm's Length Principle, as stipulated in PER - 25 / PJ / 2017 on Implementation of the Determination of the Amount of Debt Between Company and Capital for the Need of Calculating Income Tax and Procedures for Private Overseas Private Debt Reporting. Note that if PT X makes loans to an affiliate, then the amount of interest must accord with the Arm's Length Principle, for interest payments are not considered dividends.

\section{b) Applying for Determination of Remote Areas}

In preliminary $\mathrm{CCoW}$ provisions in Appendix $\mathrm{F}$, point 7 establishes that Benefit in Kind (BIK) may be charged as a deductible expense. However, in the CCoW amendment, $\mathrm{BIK}$ is no longer a deductible expense. PT $\mathrm{X}$ has expenses related to BIK at its site, for instance, catering, mess, transportation, clinic and healthcare facilities for employees, sports facilities, and places of worship that are nondeductible expense. To deduct such expenses, PT X can apply for Stipulation of Certain Regions in accordance with Regulation of the Minister of Finance No. 83/PMK.03/2009 regarding the Provision of Food and Beverage for All Employees and Replacement or Rewards in the Form of Natura and Enjoyment in Certain Regions and Related to the Implementation of the Deductible Work of the Employer's Gross Income (PMK 83/2009). The cost of PT X in 2017 was as follows.

Without application for Regional Specific Facilities, PT X must pay a fee of USD 3,708,180.58, which becomes nondeductible expense. With application for Specific Region Determination, tax savings in 2018 can amount to: USD 3,708,180.58 x 25\%=USD 927,045 or Rp. 12,940,623,172.08 (Rate 1 USD = Rp 13,959.00).

\begin{tabular}{|l|l|l|}
\hline $\begin{array}{l}\text { Nomor akun/ } \\
\text { No asset }\end{array}$ & Deskripsi & Jumlah (USD) \\
\hline 51103100 & $\begin{array}{l}\text { Mess \& Camp } \\
\text { (makanan) }\end{array}$ & $1,378,020.00$ \\
\hline $\begin{array}{l}\text { B07-FA05-C040- } \\
000001\end{array}$ & $\begin{array}{l}\text { Depresiasi: Muara } \\
\text { Tuhup Strockpile \& } \\
\text { Camp P }\end{array}$ & $1,899,981.10$ \\
\hline $\begin{array}{l}\text { B07-FA05-B010- } \\
000014\end{array}$ & $\begin{array}{l}\text { Depresiasi: Tuhup Km } \\
\text { 26 Camp \& } \\
\text { Accomodation }\end{array}$ & $235,882.16$ \\
\hline $\begin{array}{l}\text { B07-FA05-B010- } \\
000006\end{array}$ & $\begin{array}{l}\text { Depresiasi: Medical } \\
\text { Centre }\end{array}$ & $80,644.31$ \\
\hline 50705000 & $\begin{array}{l}\text { Employee Clinic \& } \\
\text { First Aid Expenses }\end{array}$ & $113,653.00$ \\
\hline Total & \multicolumn{2}{|l}{$3,708,180.58$} \\
\hline
\end{tabular}

c) Calculate assets depreciation that still have NBV in 2018 with accelerated depreciation, for instance, MIA refueling station, conveyor, MT Port Crushing, etc

Intangible assets and amortization of intangible assets obtained by PT X after the signature date of the CCoW amendment are depreciated based on provisions of Law 36/2008 in Article 11, paragraph (6). However, fixed assets acquired and amortized under the 1994 Income Tax Law are amortized according to the Income Tax Act 1994 until the assets' expiration of useful life.

\section{d) Tax administration on CIT}

To avoid administrative sanction, tax administration must be considered, for instance, the tariff of corporate income tax to $25 \%$, rate of withholding/collection of income tax to another party in accordance with prevailing provisions, period of settlement, and reporting income tax return, such as:

a) Settling the CIT payment and reporting CIT return on time, pursuant to prevailing regulation (end of third month changed to end of fourth month).

b) Apply CIT tax rate and witholding tax rate pursuant to prevailing regulation, for instance, WHT 23 rate of $6 \%$ and $7.5 \%$ changed to $2 \%$.

\section{B. Value Added Tax}

1) Optimizing restitution process period 2017 amount IDR 447.811.261.749

PT X started production in 2015 when coal was still a VAT-able good, so input tax was obtained before PT X productions could be credited. In addition, input tax obtained to generate coal production until December 2017 may also be credited, so PT X can recover VAT input until December 2017.

\section{2) Minimize use of third party services}

Using a third party service, PT X must pay VAT on the profit margin charged by the contractor. Minimizing use of a third party can minimize VAT, thus making VAT more efficient.

\section{3) VAT administration compliance}

PT X can no longer be a VAT collector; thus, VAT invoices received from vendors must have the 01 code. In 
addition, PT X must pay and report VAT on time, pursuant to the prevailing regulation.

\section{Import duty and import facilities}

\section{1) Import duty}

PT X has the right to apply for exemption of import duty with several alternatives, including through:

a) Exemption or relief of import duty and/or import VAT based on Ministry of Finance (MoF) no. 259/2016. Exemption or relief of import duty and import VAT exemption may be granted by using a Masterlist facility approved by BKPM on condition that its contract specifies exemption or relief of duty entry on import of goods in the CCoW.

b) Exemption of import duty can also be submitted based on MoF no. 176/PMK.011/ 2009, last modified by MoF No. 188/PMK.010/2015 on the Exemption of Import Duty on the Import of Machinery and Goods and Materials for Development or Industrial Development in the Framework of Investment.

c) In the event that the Masterlist facility can be obtained, PT X may use import duty through a Free Trade Agreement (FTA) facility with some countries, as long as the import of goods is completed with a Certificate of Origin (COO) issued by ASEAN, i.e., Korea, Japan, China, Australia, New Zealand, India, and Pakistan. To optimize this facility, PT X is expected to make an agreement with the contractor to provide $\mathrm{COO}$.

\section{2) Import $V A T$}

Import VAT exemption can be obtained through the Masterlist in relation to an application for exemption or relief of import duty and/or import VAT exemption based on PMK No. 259/2016. Import of capital goods should be done within 10 years after the operation period to enable the import duty facility to be utilized optimally.

\section{Adequacy of Inspection Personnel}

The CCoW amendment did not change the royalty rate from $13.5 \%$, while other PNBP also remains prevailing law. Furthermore, most regional taxes are official assessments, so administrative compliance from collection, settlement, and reporting of regional tax and PNBP is necessary.

\section{CONCLUSION}

\section{A. Conclusions}

Based on the foregoing analysis, we conclude the following:

- The amendment of the 3rd Generation CCoW shall be conducted to fulfill the mandate of Article 169 of the Minerba Law. Provisions in the CCoW article that shall be in accordance with the Minerba Law include the tax provision and the ETR increase of $6 \%$.

- After the CCoW amendment, when the tax treatment regime changed from provisions of the Act of 1994 to current prevailing provisions, tax management became necessary. PT $\mathrm{X}$ can save on taxes by utilizing existing tax facilities in the prevailing provisions, including:

a) Changes on provision of DER

b) Depreciation of assets based on accelerated depreciation requirements pursuant to Appendix F CCoW.

c) BIK received by employees is not a deductible expense.

d) Changes to provisions on VAT input are creditable.

e) Changes in land and building and fixed fee stipulations

f) Administrative provisions such as the new income tax rate, the tax withholding rate, and the VAT administration provision. Additionally, PT $\mathrm{X}$ is also no longer a VAT collector.

PT X must propose several tax facilities applicable to prevailing provisions so as to achieve tax savings, including:

a) Application for the Stipulation of Certain Regions so that BIK can be deductible expense

b) If PT X imports, it can apply for exemption of import duty, import VAT, and income tax article 22.

To avoid administrative sanctions, PT X should establish operational standards (SOPs) to comply with all tax administration provisions according to prevailing provisions for VAT, corporate income tax, withholding and income tax, and import and local taxes, and PNBP.

Because this research has some limitations, further research should include companies with more variables for calculating ETR, such as exceeding the DER ratio. Other studies should research companies not yet in production or not yet having reached the operational stage for assessment of VAT input treatment to examine whether VAT input can be recovered when the company reaches the production stage.

\section{ACKNOWLEDGMENT}

This research was presented in the The 3rd Asia-Pacific Forum for Research in Social Sciences and Humanities 2018 hosted by University of Indonesia. We appreciate valuable feedback and comments from the conference participants to improve our research paper.

In addition, we also thank Bapak Jul Seventa Tarigan Ak., MA from PT X and Bapak Iqbal from Ministry of Energy and Mineral Resources who provided his insight and expertise in tax and coal mining industry.

\section{REFERENCES}

[1] A. Soemanatta, "Perlakuan perpajakan perusahaan penambangan batubara generation i (studi kasus perusahaan PT.X)," Tesis Program Pascasarjana Akuntansi, Jakarta, 2003.

[2] C. A. Pohan, "Manajemen perpajakan strategi perencanaan pajak dan bisnis," Gramedia, Jakarta, 2017.

[3] E. Suandy, Perencanaan Pajak. Salemba Empat, Jakarta, 2003.

[4] D. S. Callihan, "Corporate effective tax rates: a syntesis of the literature,” J. Account. Lit., vol. 13, pp.1-43, 1994. 
[5] Kementerian Keuangan Republik Indonesia, "Pajak pengahasilan," Undang-Undang Republik Indonesia Nomor 36 Tahun 2008, Direktorat Jenderal Pajak, Jakarta.

[6] Kementerian Keuangan Republik Indonesia, "Pajak pertambahan nilai barang dan jasa dan pajak penjualan atas barang mewah," UndangUndang Republik Indonesia Nomor 42 Tahun 2009, Direktorat Jenderal Pajak, Jakarta.

[7] Kementerian Keuangan Republik Indonesia, "Ketentuan umum perpajakan," Undang-Undang Republik Indonesia Nomor 28 Tahun 2007, Direktorat Jenderal Pajak, Jakarta.

[8] J. W. Creswell, Research Design: Qualitative, Quantitative, and Mixed Methods Approaches, 4th ed., SAGE Publications, Inc. California, 2014

[9] Afrizal. "Metode penelitian kualitatif sebuah upaya mendukung penggunaan penelitian kualitatif dalam berbagai disiplin ilmu," Raja Grafindo Persada, Jakarta, 2014.

[10] Ikatan Akuntasi Indonesia (IAI), "Akuntansi pajak penghasilan," Pernyataan Standar Akuntansi Keuangan Nomor 46 (Revisi 2017), DSAK-IAI, Jakarta.
[11] A. Irwandy, Batubara Indonesia, Gramedia, Jakarta, 2014.

[12] Kementerian Energi dan Sumber Daya Mineral Republik Indonesia, "Perjanjian karya pengusahaan pertambangan batubara antara PT X dan pemerintah indonesia," Jakarta, 1996.

[13] Kementerian Energi dan Sumber Daya Mineral Republik Indonesia, "Amandemen perjanjian karya pengusahaan pertambangan batubara antara PT X dan pemerintah indonesia, Jakarta, 2017.

[14] Keputusan Presiden No. 49 Tahun 1981, "Ketentuan-ketentuan pokok perjanjian kerjasama pengusahaan tambang batubara antara perusahaan negara tambang batubara dan kontraktor swasta," Lembaran negara tahun 1981, Jakarta.

[15] G. R. Somantri, "Memahami metode kualitatif," Makara Sosial Humaniora vol. 9(2), pp. 57-65, 2005.

[16] M. Syaifuddin, "Hukum kontrak, memahami kontrak dalam perspektif, filsafat, teori, dogmatik, dan perikatan hukum, seri pengayaan hukum perikatan,” Mandar Maju, Bandung, 2012. 